\title{
PENERAPAN MODEL PEMBELAJARAN KOOPERATIF SNOWBALL THROWING UNTUK MENINGKATKAN HASIL BELAJAR SISWA PADA PEMBELAJARAN IPS
}

\author{
Ani Rosidah \\ anirosidah.cjr@gmail.com \\ Universitas Majalengka
}

\begin{abstract}
ABSTRAK
Penelitian ini dilatar belakangi rendahnya hasil belajar siswa pada pelajaran Ilmu Pengetahuan Sosial (IPS) materi Peninggalan sejarah dari masa HinduBudha dan Islam di kelas V SD Negeri Kadudampit Kecamatan Cilaku Kabupaten Cianjur. Penelitian ini bertujuan untuk meningkatkan hasil belajar siswa pada pembelajaran IPS materi Peninggalan Sejarah dari Masa HinduBudha dan Islam di Indonesia kelas V SD Negeri Kertabasuki II dengan menerapkan model pembelajaran Tipe Snowball Throwing. Pendekatan yang dilakukan dalam penelitian ini adalah Penelitian Tindakan Kelas (PTK) yang dilaksanakan dalam 2 siklus pembelajaran dengan frekuensi 2 tindakan pada tiap siklus dengan 4 tahap, yaitu perencanaan, pelaksanaan, pengamatan, dan refleksi. Data dikumpulkan melalui lembar observasi, instrumen tes dan dokumentasi. Data hasil penelitian yang telah diolah dan dianalisis diperoleh keterangan, bahwa hasil belajar siswa dalam pembelajaran IPS materi Peninggalan Sejarah dari Masa Hindu-Budha dan Islam, data dengan diterapkannya model pembelajaran tipe Snowball Throwing di kelas V SD Negeri Kertabasuki II telah mengalami peningkatan terbukti diperoleh data dari hasil pembelajaran siklus I siswa mendapat nilai $\geq 70 \mathrm{ke}$ atas $(\mathrm{KKM})=15$ orang atau $71,42 \%$ dengan nilai rata-rata 76,61. Sedangkan hasil pembelajaran siklus II siswa yang mendapat nilai $\geq 70(\mathrm{KKM})=18$ orang atau $85,71 \%$ dengan nilai rat-rata 78,09. Data tersebut menunjukkan bahwa penerapan model pembelajaran tipe Snowball Throwing dapat meningkatkan hasil belajar siswa. Saran penulis untuk menerapkan Model Pembelajaran tipe Snowball Throwing dalam pembelajaran karena membuat siswa aktif dan antusias dalam proses pembelajaran.
\end{abstract}

Kata Kunci :Model Pembelajaran Tipe Snowball Throwing. Hasil Belajar Siswa 


\section{PENDAHULUAN}

Sekolah dasar sebagai intitusi pendidikan, memegang peranan yang cukup penting dan strategis. Dikatakan penting dan strategis karena melalui pendidikan dasar secara formal anak didik pertama kali akan memperoleh pengalaman pendidikan. Di lembaga ini pertama kali anak mengenal berbagai keterampilan dasar seperti menulis, membaca, dan berhitung.

Dalam Undang-Undang sistem pendidikan Nasional Nomer 20 Tahun 2003 dinyatakan bahwa:

Pendidikan adalah usaha sadar terencana untuk mewujudkan suasana belajar dan proses pembelajaran agar peserta didik secara aktif mengembangkan potensi dirinya untuk memiliki kekuatan spiritual keagamaan, pengendalian diri, kecerdasan, akhlak mulia serta keterampilan yang diperlukan dirinya, masyarakat, bangsa, dan negara.

Undang-Undang sistem pendidikan nasional Nomer 20 Tahun 2003 menegaskan bahwa pendidikan dasar merupakan jenjang yang melandasi jenjang pendidikan menengah. Dengan demikian dapat dipastikan bahwa pendidikan dasar akan sangat menentukan keberhasilan belajar pada jenjang berikutnya.

Pernyataan diatas menunjukkan kualitas pendidikan sangat dipengaruhi oleh pendidikan dasar, artinya semakin bagus kualitas pendidikan dasar, maka semakin bagus pula kualitas pendidikan pada jenjang atas, oleh karena itu, sudah sewajarnya masalah pendidikan dasar menjadi perhatian dari berbagai pihak.

Pada kurikulum sekolah dasar sekarang yaitu kurikulum tingkat satuan pendidikan (KTSP), ilmu pengetahuan sosial yang disingkat IPS merupakan salah satu ilmu pengetahuan yang diajarkan dalam pendidikan di Indonesia mulai dari kelas I sampai dengan kelas VI. Pendidikan dan pengajaran IPS memiliki peran yang sangat strategis baik di tinjau dari aspek akademik maupun kepentingan berbangsa dan bernegara.

Proses pembelajaran akan menghasilkan perubahan-perubahan dalam pengetahuan, keterampilan, dan sikap yang tercermin dalam hasil belajar siswa. Hasil belajar siswa adalah perolehan hasil yang dicapai siswa dalam usaha belajarnya sebagaimana dicantumkan dalam nilai rapornya. Melalui hasil belajar seorang siswa dapat mengetahui kemajuankemajuan yang telah dicapainya dalam belajar. Seorang siswa dikatakan telah mencapai perkembangannya secara optimal apabila siswa dapat memperoleh pendidikannya dan hasil belajar yang sesuai dengan bakat, kemampuan dan minat yang dimilikinya.

Berdasarkan hasil observasi di lapangan pada mata pelajaran IPS kelas V hasil belajar siswa rendah. Hal ini terlihat dari nilai ujian akhir semester genap dalam mata pelajaran IPS, dimana sebagian besar siswa kelas V di SD Negeri Kadudampit yaitu sebesar $71 \%$ memperoleh nilai IPS dibawah KKM yaitu 70. Kondisi tersebut menunjukkan rendahnya hasil belajar siswa dalam mata pelajaran IPS.

Setiap lembaga mengharapkan siswa memperoleh hasil belajar berupa nilai sesuai dengan Kriteria Ketuntasan Minimal (KKM) yang telah ditetapkan. Hasil belajar yang ideal dengan indikator keberhasilan yang diharapkan adalah $75 \%$ dari jumlah siswa mencapai hasil belajar dengan kriteria baik. Untuk meningkatkan hasil belajar siswa guru dapat menggunakan model pembelajaran untuk membangkitkan motivasi belajar siswa, menggunakan berbagai fasilitas belajar dalam menyampaikan materi pelajaran sehingga pembelajaran lebih konkrit dan nyata.

Guru hendaknya menerapkan model pembelajaran yang menuntut dan menekankan keterlibatan siswa secara aktif dalam memperoleh dan mengorganisasikan pengetahuan sehingga melatih siswa 
belajar mandiri dan meningkatkan kemampuan berpikir. Salah satu model pembelajaran yang dapat diterapkan adalah model pembelajaran kooperatif tipe Snowball Throwing.

"Model pembelajaran kooperatif tipe Snowball Throwing adalah suatu model pembelajaran yang diawali dengan pembentuka kelompok yang diwakili ketua kelompok untuk mendapat tugas dari guru kemudian masing-masing siswa membuat pertanyaan yang dibentuk seperti bola (kertas pertanyaan) lalu dilempar ke siswa lain yang masing-masing siswa menjawab pertanyaan dari bola yang diperoleh" ( Huda 2013 : 226).

Model pembelajaran kooperatif tipe Snowball Throwing dapat menigkatkan aktivitas dan kreatifitas siswa, melatih siswa belajar mandiri dalam pengetahuan berdasarkan diskusi, mengembangkan kemampuan berpikir siswa dalam mendiskusikan dan meyelesaikan tugas belajar, mengembangkan kemampuan mengemukakan pendapat, meningkatkan kemampuan menjelaskan kembali materi yang diperoleh berdasarkan diskusi, dan meningkatkan hasil belajar siswa.

Berdasarkan uraian diatas maka peneliti sangat tertarik untuk melakukan penelitian dengan judul " Penerapan Model Pembelajaran kooperatif Tipe Snowball Throwing Untuk Meningkatkan Hasil Belajar Siswa pada Pelajaran IPS Materi Peniggalan Sejarah dari Masa HinduBudha dan Islam di Indonesia Kelas V SD Negeri Kadudampit Kecamatan Cilaku Kabupaten Cianjur.

Berdasarkan latar belakang diatas, peneliti merumuskan masalah sebagai berikut yaitu bagaimanan penerapan model pembelajaran kooperatif tipe Snowball Throwing untuk meningkatkan hasil belajar siswa pada pembelajaran IPS materi Peninggalan Sejarah dari Masa Hindu-Budha dan Islam di Indonesia kelas V SD Negeri Kadudampit Kabupaten Cianjur?. Tujuan penelitian ini adalah untuk mengetahui penerapan model pembelajaran kooperatif tipe Snowball Throwing dan hasil belajar siswa pada pembelajaran IPS materi Peninggalan Sejarah dari Masa Hindu-Budha dan Islam di Indonesia kelas V SD Negeri Kadudampit Kabupaten Cianjur.

Adapun manfaat yang dapat diambil dari penelitian ini ada dua yaitu manfaat teoritis dan manfaat praktis. Untuk lebih jelasnya, peneliti uraikan sebagai berikut.

Manfaat teoritis adalah manfaat yang dapat membantu kita untuk lebih memahami suatu konsep atau teori dalam suatu disiplin ilmu. Manfaat teoritis pada penelitian tindakan kelas kali ini adalah meningkatkan hasil belajar Pendidikan Ilmu Pendidikan Sosial khususnya materi Peninggalan Sejarah dari Masa HinduBudha dan Islam di Indonesia pada kelas V SD Negeri Kadudampit serta menambah wawasan mengenai penggunaan model pembelajaran yang tepat sesuai dengan materi dan kondisi yang ada.

Manfaat praktis ialah manfaat yang bersifat terapan dan dapat segera digunakan untuk keperluan praktis, misalnya memecahkan suatu masalah, membuat keputusan, memperbaiki suatu program yang sedang berjalan. Manfaat praktis pada penelitian tindakan kelas kali ini akan diuraikan manfaat praktis dari ketiganya.

Pertama bagi siswa, penelitian ini bermanfaat untuk meningkatkan ketertarikan dan antusias siswa untuk mempelajari mata IPS khususnya materi peninggalan Sejarah dari masa HinduBudha dan Islam di Indonesia, memberikan kemudahan memahami materi, memberikan suasana menyenangkan dan tidak monoton dalam pembelajaran, serta meningkatkan hasil belajar.

Kedua bagi guru, penelitian ini bermanfaat untuk menambah wawasan guru bahwa materi tokoh-tokoh penting dalam Peninggalan Sejarah dari Masa Hindu-Budha dan Islam di Indonesia pada 
kelas V SD Negeri Kadudampit perlu disampaikan secara bermakna yakni dengan memperhatikan tiga ranah belajar. Penelitian ini dapat dijadikan acuan untuk membelajarkan materi Ilmu Pendidikan Sosial kepada siswa dengan cara yang menyenangkan serta membuat siswa tidak bosan sehingga bisa mendapatkan hasil yang optimal.

Ketiga bagi sekolah, manfaat praktis bagi sekolah ialah memotivasi sekolah untuk selalu berinovasi dalam penggunaan model pembelajaran. Inovasi penggunaan model pembelajaran pada nantinya akan meningkatkan hasil belajar siswa. Penigkatan hasil belajar siswa akan meningkatkan prestasi sekolah. Dari pernyataan tersebut peneliti simpulkan manfaat penelitian ini secara praktis ialah dapat meningkatkan prestasi sekolah.

\section{Kajian pustaka}

Pengertian belajar adalah suatu proses perubahan tingkah laku individu melalui interaksi dengan lingkungan Winkel (dalam Purwanto, 2008;39) berpendapat bahwa "belajar adalah aktivitas mental atau psikis yang berlangsung dalam interaksi aktif dengan lingkungan yang menghasilkan perubahanperubahan dalam pengetahuan, keterampilan dan siakp". Djamarah (2010: 13) mengemukakan bahwa belajar adalah serangkaian kegiatan jiwa raga untuk memperoleh suatu perubahan tingkah laku sebagai hasil dari pengalaman individu dan interaksi dengan lingkungannya menyangkut kognitif, afektif dan psikomotorik. Belajar adalah suatu proses perubahan tingkah laku individu melalui interaksi dengan lingkungan. Didalam interaksi inilah terjadi serangkaian pengalaman-pengalaman belajar. Oleh karena itu belajar adalah semua sentuhan pribadi dengan lingkungan yang menimbulkan prilaku. Menurut Wingo (dalam Sumiati, 2011:41) ada 3 prinsip belajar yaitu:
a. Hasil Belajar Sepatutnya menjangkau banyak segi
b. Belajar diperoleh berkat pengalaman
c. Belajar merupakan suatu kegiatan yang mempunyai tujuan

Wanger ( dalam Huda, 2013: 2) mengatakan bahwa "pembelajaran bukanlah aktivitas, sesuatu yang dilakukan oleh seseorang ketika ia tidak melakukan aktivitas yang lain. Pembelajaran bukanlah juga sesuatu yang berhenti dilakukan oleh seseorang lebih dari itu pembelajaran bisa terjadi dimana saja dan pada level yang berbeda-beda, secara individual, kolektif, ataupun sosial".salah satu bentuk pembelajaran adalah pemrosesan informasi.

Soedijarto (dalam purwanto, 2008: 46) mengemukakan bahwa "hasil belajar merupakan sebagai tingkat penguasaan yang dicapai oleh mahasiswa atau siswa dalam mengikuti proses belajar mengajar sesuai dengan tujuan pendidikan yang ditetapkan". Jadi hasil belajar adalah perubahan tingkah laku manusia akibat belajar, perubahan tingkah laku disebabkan karena dia mencapai penguasaan atas sejumlah bahan yang diberikan dalam proses belajar mengajar, pencapaian itu didasarkan atas tujuan mengajar yang telah ditetapkan. Hasil itu dapat berupa perubahan dalam aspek kognitif, apektif, dan psikomotorik.

Menurut Bloom (dalam Purwanto, 2008:50) ada tiga ranah yaitu:

a. Ranah kognitif adalah perubahan perilaku yang terjadi dalam kawasan kognisi. Proses belajar yang melibatkan kawasan kognisi meliputi kegiatan sejak dari penerimaan stimulus, penyimpanan, dan pengolahan dalam otak menjadi informasi hingga pemanggilan kembali informasi ketika diperlukan untuk menyelesaikan masalah.

b. Ranah apektif

1. Penerimaan, yang mencakup kepekaan tentang hal tertentu 
dan kesediaan memperhatikan hal tersebut.

2. Partisipasi, yang mencakup kerelaan, kesediaan memperhatikan, dan berpartisipasi dalam suatu kegiatan.

3. Penilaian dan penentuan sikap, yang mencakup menerima suatu nilai, menghargai, mengakui, dan menentukan sikap.

4. Organisasi, yang mencakup kemampuan membentuk suatu sistem nilai sebagai pedoman dan pegangan hidup.

5. Pembentukan pola hidup, yang mencakup kemampuan menghayati nilai dan membentuknya menjadi pola nilai kehidupan pribadi.

c. Ranah psikomotorik

Beberapa ahli mengklasifikasi hasil belajar psikomotori. hasil belajar disusun berdasarkan urutan mulai dari yang paling rendah dan sederhana sampai yang paling tinggi hanya dapat dicapai apabila siswa telah menguasai hasil belajar yang lebih rendah.

Berhasil atau tidaknya seseorang dalam belajar disebabkan beberapa faktor yang mempengaruhi pencapaian hasil belajar. Menurut Slameto ( 2010:54) faktor-faktor yang mempengaruhi belajar banyak jenisnya, tetapi dapat digolongkan menjadi dua golongan saja, yaitu faktor intern dan faktor ekstern. Faktor intern adalah faktor yang berasal dari dalam diri individu yang sedang belajar. Ada tiga faktor yang menjadi faktor intern yaitu:

a. Faktor jasmaniah

b. Faktor fsikologis

c. Faktor kelelahan

Faktor ekstern adalah faktor yang ada diluar individu. Faktor intern yang berpengaruh terhadap belajar menurut Slameto (2010:60) dikelompokkan menjadi 3 faktor yaitu faktor keluarga, faktor sekolah, dan faktor masyarakat.
Berdasarkan uraian diatas model pengajaran yang diterapkan oleh guru untuk menyampaikan materi pembelajaran termasuk kedalam faktor eksternal yang kemudian secara berkelanjutan akan mempengaruhi faktor internal anak. Faktor eksternal yang dimaksudkan dalam hal ini adalah faktor yang berasal dari sekolah yaitu model pembelajaran. Model pembelajaran yang inovatif akan berpengaruh terhadap minat dan motivasi siswa dalam mengikuti proses pembelajaran. Salah satu model pembelajaran yang inovatif dan menyenangkan untuk siswa adalah model pembelajaran tipe kooperatif tipe Snowball Throwing. Dengan model pembelajaran melalui tipe ini diharapakan minat dan motivasi anak untuk belajar akan lebih meningkat lagi dan kemudian akan berdampak pada hasil belajar siswa.

Suprijono (2009: 54) memandang bahwa pembelajaran kooperatif adalah konsep yang lebih luas meliputi jenis kerja kelompok termasuk bentuk-bentuk yang lebih dipimpin oleh guru atau diarahkan oleh guru. Menurut Isjoni (2011: 20) pembelajaran kooperatif dapat didefinisikan sebagai suatu pendekatan mengajar dimana murid bekerja sama diantara satu sama lain dalam kelompok belajar yang kecil untuk menyelesaikan tugas individu atau kelompok yang diberikan oleh guru. Pembelajaran kooperatif secara sadar menciptakan interaksi yang silih asah sehingga sumber balajar bagi siswa bukan hanya guru dan buku ajar tetapi juga sesama siswa.

Snowball secara etimologi berarti bola salju, sedangkan Throwing artinya melempar. Snowball Throwing secara keseluruhan dapat diartikan melempar bola salju. Dalam pembelajaran Snowball Throwing, bola salju merupakan kertas yang berisi pertanyaan yang dibuat oleh siswa kemudian dilempar kepada temannya sendiri untuk dijawab. Menurut Huda (2013:226) model pembelajaran Snowball Throwing adalah suatu model 
pembelajaran yang diawali dengan pembentukan kelompok yang diawali ketua kelompok untuk mendapat tugas dari guru kemudian masing-masing murid membuat pertanyaan yang dibentuk seperti bola (kertas pertanyaan) lalu dilempar kemurid yang lain masing-masing murid menjawab pertanyaan dari bola yang diperoleh. Pembelajaran Snowball Throwing melatih siswa untuk lebih tanggap menerima pesan dari orang lain, dan menyampaikan pesan tersebut kepada temannya dalam satu kelompok.

Langkah-langkah pembelajaran kooperatif tipe Snowball Throwing menurut Suprijono (2009: 128) yaitu sebagai berikut.

Pertama guru menyampaikan materi yang akan disajikan, yang kedua guru membentuk kelompok-kelompok dan memanggil masing-masing ketua kelompok untuk memberikan penjelasan tentang materi, ketiga masing- masing ketua kelompok kembali ke kelompok masing-masing kemudian menjelaskan materi yang disampaikan oleh guru kepada temannya, keempat masing-masing siswa diberikan satu lembar kertas kerja untuk menuliskan satu pertanyann apa saja yang menyangkut materi yang sudah dijelaskan oleh ketua kelompok, kelima kertas yang berisi pertanyaan tersebut dibuat seperti bola dan dilempar dari satu siswa ke siswa yang lain selama \pm 15 menit, selanjutnya setelah siswa dapat satu bola atau satu pertanyaan diberikan kesempatan kepada siswa untuk menjawab pertanyaan yang tertulis dalam kertas yang berbentuk bola tersebut secara bergantian , kemudian evaluasi dan terakhir penutup.

Istilah IPS sendiri merupakan terjemahan dari Socialstudies. Menurut Sapriya (2009:43) khusus IPS Sekolah Dasar materi pelajaran dibagi menjadi dua bagian yaitu materi sejarah dan materi pengetahuan sosial. IPS diartikan sebagai "ilmu yang mempelajari bidang kehidupan manusia dimasyarakat, mempelajari gejala dan masalah sosial yang terjadi dari bagian kehidupan tersebut". Artinya IPS diartikan sebagai kajian terpadu dari ilmu-ilmu sosial serta untuk mengembangkan potensi kewarganegaraan. Tujuan dari pembelajaran IPS adalah mencerdaskan kehidupan masyarakat dengan dasar nilainilai moral dan etika yang tinggi dan menjunjung tinggi nilai budaya bangsa serta membentuk peserta didik yang memiliki ilmu pengetahuan, keterampilan, wawasan kebangsaan, dan etika sosial, berakhlak sosial yang tinggi.

\section{Metodologi Penelitian}

Waktu penelitian dilaksanakan pada semester ganjil tahun ajaran 2015/2016 dari mulai bulan Juli sampai Agustus. Penelitian dilaksanakan di SD Negeri Kadudampit Kecamatan Cilaku Kabupaten Cianjur. Subjek dalam penelitian ini yaitu siswa kelas V SD Negeri Kadudampit sebanyak 21 siswa.

Sumber dalam penelitian ini adalah siswa kelas V SD Negeri Kadudampit dan guru kelas V SD Negeri Kertabasuki II. Teknik yang dilakukan dalam pengumpulan data yaitu observasi, tes, dan dokumentasi.

\section{Hasil Penelitian dan Pembahasan}

Peneliti melakukan pengamatan untuk mengetahui kondisi awal, salah satu kondisi awal menunjukkan nilai rata-rata masing tergolong rendah atau masih dibawah KKM (70). Nilai rata-rata siswa dalam pembelajaran IPS seblum tindakan adalah 65,95 berdasarkan total jumlah siswa sebanyak 21 orang, siswa yang memenuhi KKM 8 siswa atau sebesar $38,09 \%$ dari total jumlah siswa.

Hasil pengamatan tindakan kelas siklus I dapat dijelaskan bahwa hasil belajar IPS melalui model pembelajaran kooperatif tipe Snowball Throwing pada siswa kelas V SD Negeri Kadudampit mengalami peningkatan jumlah siswa yang tuntas yakni menjadi 15 orang siswa $(71,42 \%)$. Dari hasil tersebut maka penelitian akan dilanjutkan kekegiatan tindakan kelas siklus II karena siswa yang mendapat nilai diatas indikator 
keberhasilan dengan nilai minimal 70 masih berjumlah 15 orang $(71,42 \%)$ dan yang belum mencapai nilai minimal 70 berjumlah 6 orang $(28,5 \%)$. Hal ini menunjukkan bahwa pelaksanaan tindakan kelas siklus I belum mencapai indikator kinerja yang ditetapkan yakni hasil belajar siswa kelas V SD Negeri Kadudampit bisa mencapai $75 \%$.

Dari pelaksanaan tindakan kelas siklus II nampak bahwa hasil belajar IPS melalui model pembelajaran kooperatif tipe Snowball Throwing pada siswa kelas V SD Negeri Kadudampit meningkat dan mencapai indikator kinerja yang telah ditetapkan. Jumlah siswa yang mendapatkan nilai tuntas menjadi 18 orang siswa $(85,71 \%)$. Hal ini membuktikan bahwa pelaksanaan tindakan kelas tidak dilanjutkan lagi karena sudah mencapi indikator kinerja yakni hasil belajar siswa mencapai $75 \%$.

Pelaksanan penelitian tindakan kelas yang dilaksanakan dua siklus bertujuan untuk meningkatkan hasil belajar mata pelajaran IPS melalui penerapan model pembelajaran kooperatif Snowball Throwing pada siswa kelas V SD Negeri Kadudampit dan melatih siswa untuk lebih tanggap menerima pesan dari orang lain dan menyampaikan pesan tersebut kepada temannya dalam satu kelompok.

\section{Simpulan dan Saran Simpulan}

Berdasarkan hasil penelitian dan pembahasan disimpulkan bahwa model pembelajaran kooperatif tipe Snowball Throwing dapat diterapkan pada materi peniggalan sejarah dari masa Hindu-Budha dan Islam di Indonesia pada pembelajaran IPS kelas V SD Negeri Kadudampit Kecamatan Cilaku Kabupaten Cianjur dan pembelajaran pendidikan IPS materi peniggalan sejarah dari masa Hindu-Budha dan Islam di Indonesia yang dilaksanakan model pembelajaran tipe Snowball Throwing dapat meningkatkan hasil belajar siswa yaitu dilihat dari siklus I jumlah siswa dari 21 orang ada 15 orang yang tuntas sebanyak $71,42 \%$ meningkat di siklus II menjadi 18 orang dari 21 siswa yang dikatakan tuntas yaitu $85,71 \%$. Oleh karena itu hasil balajar siswa melalui model pembelajaran tipe Snowball Throwing dapat meningkatkan hasil belajar siswa terbukti dari hasil peningkatan siklus I ke siklus II.

\section{Saran}

Saran yang bisa diberikan pertama untuk pihak guru, diharapkan guru dapat mengembangkan dan menerapkan pada materi dan pembelajaran lain. Guru juga di tuntun untuk lebih kreatif dan inovatif dalam menyampaikan pembelajaran sehingga sehingga siswa tidak merasa jenuh dan bosan dalam mengikuti pembelajaran.

Untuk siswa, siswa dapat belajar sambil melakukan permainan dan menemukan sendiri gagasan atau materi tersebut. Siswa diharakan mampu bersikap aktif dan kreatif serta mampu berpikir logis dalam mengikuti pembelajaran.

Untuk lembaga, selain dengan ilmu dan teknologi lembaga untuk meningkatkan mutu pendidikan dan sumber daya manusia, lembaga diharapkan mampu memberikan dukungan yang maksimal untuk meningkatkan kualitas pembelajaran dengan melengkapai fasilitas pembelajaran, meningkatkan profesionalisme dan membuka diri terhadap berbagai inovasi pembelajaran. Salah satunya yaitu dengan menerapkan model pembelajaran kooperatif tipe Snowball Throwing yang telah terbukti keberhasilannya dalam penelitian.

\section{Daftar Pustaka}

Arikunto.(2010).Prosedur Penelitian suatu Pendekatan Praktik. Jakarta: Rineks cipta.

\section{Djamarah.(2010). Strategi Belajar Mengajar. Jakarta: Rineka cipta.}


Huda.(2013). Model-Model Pengajaran dan Pembelajaran, Yogyakarta: Pustaka Belajar.

Isjoni.(2011). Pembelajaran Kooperatif. Yogyakarta: Pustaka Pelajar.

Komlasari.(2010). Model Pembelajaran Kooperatif. Bandung: Wijayakusunah.

Purwanto.(2008). Evaluasi Hasil Belajar. Yogyakarta: Pustaka Belajar.

Sapriya.(2009). Pendidikan IPS Konsep dan Pembelajaran. Bandung: Remaja Rosdakarya.

Slameto.(2010). Belajar dan Faktorfaktor yang Mempengaruhinya. Jakarta: Rineka Cipta.

Sudjana.(2009). Penilain Proses Belajar Mengajar. Bandung: Remaja Rosdakarya.

Sugiyanto.(2009). Pembelajaran Model-model Surakarta: Pustaka kooperatif.

Sumiati.(2011). Metode Pembelajaran. Bandung: CV WACANA PRIMA.

Suprijono, A.(2011). Cooperatif Learning Teort dan Aplikasi PAIKEM. Yogyakarta: Pustaka Belajar.

Syamsiyah, S. Dkk,(2008). Ilmu Pengetahuan Sosial. Jakarta: Pusat Perbukaan Depertemen Nasional.

Syamsudin, A.(2009). Psikologi Kependidikan. Bandung: PT Remaja Rosdakarya.

Syansiah, S.(2008). Ilmu Pengetahuan Sosial untuk SD/MI Kelas 5. Jakarta: Pusat Perbukuan Departemen Pendidikan Nasional.

Wiriaatmadja, R.(2005). Metode Penelitian Tindakan Kelas. Bandung: PT Remaja Rosdakarya. 